\title{
PELESTARIAN SITUS ULAK LEBAR SEBAGAI DESTINASI WISATA SEJARAH
}

\author{
Ravico' $^{1}$, Andriana Sofiarini² \\ 1 Institut Agama Islam Negeri Kerinci \\ 2STKIP PGRI Lubuklinggau
}

Alamat korespondensi: ravicoiainkerinci@gmail.com

Diterima: 15 Desember 2018; Direvisi: 20 Januari 2019; Disetujui: 22 Januari 2019

\begin{abstract}
The Ulak wide site as a relic of a human civilization in Lubuklinggau City experienced a condition of concern. Departing from these concerns, the aim of this study is to preserve so that the Ulak Lebar Site can become a Historical Tourism Destination in Lubuklinggau City. The research method uses historical methodology and the steps are heuristics, verification, interpretation and historiography with a tourism approach. As for the results of this study, the first study of the local history of a wide-ranging ulama site consisting of seven sectors needs conservation efforts. Secondly, with the preservation of the Ulak Lebar Site can be used as a historical tourist destination. So that the next generation can take important lessons on human civilization in Ulak Lebar.
\end{abstract}

Keywords: Wide Ulak Site; travel destinations.

\begin{abstract}
Abstrak
Situs Ulak lebar sebagai peninggalan dari sebuah peradaban manusia di Kota Lubuklinggau mengalami kondisi yang memperihatikan. Berangkat dari keprihatinan tersebut tujuan penelitian ini berupaya melestarian agar Situs Ulak Lebar dapat menjadi Destinasi Wisata Sejarah Kota Lubuklinggau. Adapun metode penelitiannya menggunakan menggunakan metodelogi sejarah dan langkah-langkahnya yaitu heuristik, verifikasi, interpretasi dan historiografi dengan pendekatan pariwisata. Adapun hasil penelitian ini, pertama kajian tentang sejarah lokal situs ulak lebar yang terdiri dari tujuh sektor perlu adanya upaya pelestarian. Kedua, dengan adanya upaya pelestarian Situs Ulak Lebar dapat dijadikan sebagai destinasi wisata sejarah. Agar generasi berikutnya dapat mengambil pelajaran penting peradaban manusia di Ulak Lebar.
\end{abstract}

Kata Kunci: Situs Ulak Lebar, Destinasi Wisata.

\section{A. Pendahuluan}

Sejarah kota, dengan segala perubahan dan perkembangan ternyata suatu studi yang menarik. Masa kolonial dan masa pasca-kolonial, bukanlah sebuah per-tentangan, namun, ia merupakan sebuah proses keberlanjutan antar-masa. Selain itu, jargon modernisasi ini ternyata merupakan jargon yang sama pada masa sebelumnya. Oleh karena itu, modernisasi sebagai sebuah alat dan mesin kerja tentu akan membawa berbagai kon-sekuensi terhadap para pendukung kota. Yang siap, akan menjadi pe-menang, sementara yang tidak siap, kembali dan terbukti akan menjadi pecundang (Irwanto,2010 :xix).

Melihat perkembangan Kota Lubuklinggau yang begitu pesat membuat kota ini menjadi kota terbesar kedua setelah Kota Pa-lembang. Perkembangan dengan lebel moderenitas bagaikan pedang bermata dua, di lain sisi perkem-bangan ini berdampak positif bagi kehidupan dan roda perekonomian masyarakat setempat. Di sisi lain, perkembangan ini juga "membunuh" peradaban masyarakat setempat yang dahulunya dipuja dan dipuji. Seperti peradaban 
masyarakat Lubuklinggau di Situs Ulak Lebar.

Semangat modernitas cen-derung diterjemahkan dalam bentuk pembangunan insfrastruktur, dan hal ini banyak menimpa kota-kota di Indonesia termasuk Kota Lubuk-linggau. Kusno yang dikutip oleh Asyhadi (2015:5) mengartikan kata "pembangunan" secara luas menye-rupai teori modernisasi yang mencoba memberikan identitas baru kepada generasi berikutnya tentang pengembangan insfrastruktur. Sadar atau tidak new identity bagi genersi berikutnya dengan dimulai pembangunan modern ini mengorbankan cagar budaya warisan Indonesia. misalnya upaya pengahancuran.

Proses modernisasi yang tidak procagar budaya. Pada akhirnya menghilangkan identitas kebangsaan itu sendiri. Saat ini, peninggalan peradaban Situs Ulak Lebar begitu asing ditelinga generasi penerus. Ditambah lagi, Situs Ulak Lebar yang saat ini kondisinya perlu mendapat perhatian masyarakat dan pemerintah setempat. Minimnya per-hatian ini menjadi tonggak kekhawatiran bahwa dikemudian hari, kota ini tidak memiliki identitas diri yang patut dibanggakan. Kurangnya pengetahuan generasi penerus terhadap situs ini, juga tidak lepas dari kurangnya sejarawan lokal menghistoriografi-kan sejarah ini.

Pada umumnya, sejarawan lokal masih bersifat fragmatis atau serba terkeping ini disebabkan antara lain karena sumber-sumber sejarah sangat terbatas. Sejarawan lebih tertarik pada sesuatu yang bergerak, dinamis, moving, dan tentu saja mengairahkan. Sayangnya tidak semua peristiwa dan situasi mengairahkan. Akibat dari semua ini ialah belum dimungkinkannya rekonstruksi sejarah umum

yang

memadai

(Abdullah,2005:33).

Hal kedua, di samping pengetahuan yang fragmatis, lemahnya karangka konseptual. Sejarah lokal, yang berpretensi sebagai sejarah daerah sering sekali mempercampur adukan beberapa pengertian "daerah" dalam pe-nulisan. Akibatnya terjadi pengaburan materi. Di samping itu, adanya penulisan "sejarah daerah" berdasarkan"pesanan”. Namun, tidak bisa menyalahkan sepenuhnya kepada sejarawan lokal. Kadangkala proyek penulisan sejarah daerah, yang disponsori oleh pemerintah daerah sering didukung oleh keinginan memperlihatkan parti-sipasi daerah dalam perjuangan. Hal ini tidaklah salah, hanya saja tidak menyumbang banyak bagi pendalaman pengetahuan tentang sejarah lokal (Abdullah,2005:34).

Terlepas dari semuanya, perubahan adalah upaya untuk menciptakan tatanan baru namun tidak jarang perubahan tersebut justru menghilangkan tatanan lama yang dirasakan lebih baik dari sebelumnya (Dedi,2010:1). Pesatnya pertumbuhan Lubuklinggau sebagai sebuah kota dalam kenyataannya telah mengikis roh dari wujud lamanya. Sehingga perlunya inventarisasi, dokumentasi dan kontruksi sebagai bentuk pene-lusuran sejarah masyarakat. Mene-lususri sejarah masyarakat Lubuk-linggau, tidak akan pernah lepas dari konsepsi masyarakat uluan dan iliran, yaitu sebuah konsepsi masyarakat Sumatera Selatan dalam perspktsif politik, ekonomis, sosial, dan budaya. Iliran secara historis diidentifikasikan mendapat pengaruh kuat dari ibukota (Palembang) sehingga lebih bercorak modern. Sementara, uluan masih berada dalam alam tradisional, karena sedikit mendapat sentuhan pusat ibukota 
keresidenan (Supriyanto dkk, 2010:1). Dilihat secara geografis Kota Lubuklinggau merupakan daerah uluan dengan corak tradisional.

Kehidupan masyarakat uluan terpilah-pilah dan terpisah-pisah satu sama lain dalam bentuk pemerintahan kemargaan. Marga ini berbentuk sebuah wilayah administrasi geneologis, seketurunan. Tulisan sejarah awal perkembangan pemerintahan marga di Sumatera Selatan, secara kronologis teratur dari waktu ke waktu belum diketemukan dalam suatu pustaka yang konperehensif (Supriyanto dkk, 2010:12).

Data lokal tentang marga pertama kali didapati dalam piagam SultanSultan Palembang sejak tahun 1760. Tulisan Thomas Reffles dalam tulisannya tidak pernah menyebut "Marga", sama seperti penulisan Barat lainnya, Ia memaknai kesatuan masyarakat dari sifat kekeluargaan tadi dengan istiah "suku,sumbai, kebuaian." Kesatuan-kesatuan masyarakat teritorial kemudian diikat dengan kebijakan pemerintah yang kemudian dikenal dengan Undang-Undang Simbur Cahaya (Supriyanto dkk,2010:12-13).

Kesatuan masyarakat Ulak Lebar merupakan kesatuan masya-rakat awal sebelum terbentuknya Kota Lubuklinggau. Masyarakat ini telah terbentuk secara alami. Menurut Suwandi (1996:14) me-nuturkan bahwa:

Ulak Lebar merupakan sebuah negeri yang pernah ada pada pada zamannya. Letaknya di Lembah Bukit Sulap Kota Lubuklinggau. Di bawah lembah Bukit Sulap ini terdapat sungai-sungai seperti Sungai Kasie dan Sungai Ketue yang mengalir ke arah selatan agak ke tenggara yang ber-muara di Sungai Kelingi. Hal tersebut menunjang sebuah hubungan perekonomian melalui jalur sungai sehingga dikenal dengan istilah Poros Ulu-Ilir, sebab pelayaran dari Sungai Musi yang kemudian memasuki sungai utama yaitu Sungai Kelingi, perahu dagang (Jong-jong) biasa menepi di sebelah hilir negeri Ulak Lebar.

Perkembangan selanjutnya masa kolonial, masyarakat Ulak sLebar dipaksa untuk meninggalkan negerinya dan mengisi kota baru. Akhirnya negeri Ulak Lebar hanya meninggalkan jejak arkeologis dari peradabannya seperti menhir. Bangunan-bangunan dari tradisi megalitik ini umumnya berfungsi sebagai kuburan ataupun tempat pemujaan terhadap roh leluhur. Salah satu tinggalan arkeologi dari tradisi megalitik yang berfungsi sebagai tempat pemujaan. Selain menhir ditemukan juga benteng alam sebagai perlindungan masayarakat dari serangan musuh.

Permasalahan selanjutnya, ketika survei awal banyak peninggalanpeninggalan yang terbengkalai, rusak bahkan hilang, sehingga beberapa bagian peninggalan peradaban ini tidak lagi memiliki bentuk aslinya. Oleh karena itulah, perlunya pendataan ulang, inventarisasi, dokumentasi dan rekonstruksi sejarah. Hal tersebut di atas merupakan landasan dasar perlu rekonstruksi dan historiografi terhadap Situs Ulak Lebar sebagai sejarah bukti per-adaban masyarakat Lubuklinggau.

Dari uraian di atasyang menjadi masalah pokok adalah kondisi Situs Ulak Lebar yang saat ini terbengkalai, ditambah lagi kurangnya pengetahuan masyarakat tentang situs tersebut, maka diperlukan sebuah pendekatan arkeologis untuk menginventarisasi, mendokumentasikan masalah ter-sebut. Selanjutnya, Agar menjadi pengetahuan bagi generasi mendatang diperlukan rekontruksi sejarah. Untuk mempermudah permasalahan pokok tersebut maka dirumuskan sub-sub masalah sebagai berikut: Bagaimana kondisi Situs Ulak Lebar saat ini ? dan Bagaimana pelestarian Situs Ulak Lebar 
sebagai destinasi wisata sejarah? penelitian yang diteliti untuk kemudian ditulis ini berlokasi di Ulak Lebar Kota Lubuklinggau Sumatera Selatan: Pembatasan yang jelas diperlukan karena suatu penelitian akan bermanfaat jika dilakukan secara terbatas. Dengan mengambil setting geogerafis maka diperoleh batas-batas kronologis dan kebudayaan secara jelas (Gonggong, 1998:6-7).

\section{B. Metode Penelitian}

Beradasarkan tema dan judul penelitian yang akan dikaji, maka penelitian ini menggunakan metode penelitian sejarah. Menurut Gilbert J. Garraghan, metode penelitian sejarah merupakan perangkat aturan dan prinsip yang tersusun secara sistematis untuk mengumpulkan sumber sejarah secara efektif, mengkritisi, dan mengajukan sintesa dari hasil yang dicapai dalam bentuk tertulis. Senada dengan Dengan Louis Gottshalk menjelaskan metode penelitian sejarah adalah proses menguji dan menganalisis kesaksian sejarah guna mendapatkan data yang otentik dan terpercaya, serta usaha sintesis atas data semacam itu menjadi sejarah yang dapat dipercaya (Abdurrahman,2011 :103). Oleh ka-rena itu, metode penelitian sejarah sebagai penyelidikan atas suatu masalah dengan mengaplikasikan jalan pemecahan dari perspektif historis.

\section{a. Tahapan-Tahapan Penelitian}

Secara ringkas langkah-langkah dalam penelitian sejarah dirumuskan sebagai berikut, heuristik (teknik pengumpulan data), verifikasi (teknik kritik sumber), Interprtasi (teknik analisis data) dan historiografi (teknik penulisan).

\section{Heuristik (Teknik Pengumpulan Data)}

Kegiatan awal dalam penelitian sejarah adalah langkah pengumpulan sumber data (Heuristik). Heuritik adalah mengumpulkan berbagai sumber yang terkait dengan data yang diteliti (Suryabrata, 1997:65). Namun, me-lacak mempunyai pengertian luas, tetapi juga meliputi kegiatan inventarisasi dan dokumentasi. Dalam proses pencarian dan pengumpulan data seorang peneliti dituntut memiliki pengetahuan atau sekurang-kurangnya memahami apa yang disebut arkeologi atau sejarah. Melacak jejak arkeologis Situs Ulak Lebar dilakukan beberapa cara: pertama, melalui peberitaan orang, baik langsung maupun tidak langsung. Kedua, melalui hasil kajian literatur yang mengandung petunjuk adanya temuan tentang objek yang diteliti, sumber tersebut bisa diperoleh dari arsip, doku-mentasi, laporan, dan naskah-naskah kuno (Tjandrasasmita,2009:110)

\section{Verifikasi (Teknik Kritik Sum-ber)}

Kritik adalah langkah berikutnya setelah langkah heuristik. Verifikasi adalah langkah yang mengkritik atau mengecek sumber data yang telah berhasil didapatkan. Untuk memperoleh sumber yang maksimal semua sumber yang diperoleh ditelaah dan dikritik langsung oleh penulis. Sumber-sumber sejarah yang telah diperoleh masih perlu dikritik sebab sumber data sejarah berbeda dengan sumber data ilmu sosial lainnya. Penelitian sejarah tidak mungkin dilakukan dengan metode observasi langsung seperti halnya ilmuilmu sosial lainnya, karena peristiwaperistiwa sejarah bersifat einmalig (sekali hanya terjadi sekali dan tidak akan pernah terulang kembali). Data sejarah tidak pernah lengkap dan jarang pula terdokumentasi secara baik, walaupun 
ada data yang terdoku-mentasi biasanya hanya kebetulan saja. Bahkan tidak sedikit yang menghilangkan jejak sejarah, dan masih banyak pula informasi sejarah bersifat bias dan berat sebelah (Daliman,2012: 65).

Data yang telah diperoleh dianalisis secara cermat, sehingga data yang dianggap memiliki kesenjangan karena adanya perbedaan pendapat atau perbedaan pemikiran dari narasumber maupun pengarang untuk mencari kebenaran ilmiah. Oleh karena itu, seorang sejarawan dituntut untuk tidak memihak atau condong terhadap pendapat atau pemikiran seseorang. Ibnu Khaldun dalam bukunya yang berjudul Muqaddimah, menyatakan bahwa:

\begin{abstract}
“Seorang sejarawan harus membandingkan persamaan atau perbedaan keadaan-keadaan, kini dan masa lalu. Dia harus mengetahui sebab timbulnya kesamaan dalam beberapa situasi dan sebab timbulnya perbedaan dalam situasi lainnya. Dia harus mengetahui perbedaan sumber dan awal munculnya alasan dan dorongan yang membuat semua ini terwujud (Khaldun,1986: 96)."
\end{abstract}

Mengutip pendapat Garrachan $(1964,205)$ dalam buku-nya yang berjudul " A Guide to Hisrorical Method" bahwa:

"The dissection of historical writing with a view to ascertain the sources of information from which they were compiled, is a conventional method of inquiry in scientific history. The proses must be conducted with meticulous care. For credibility of a narrative, as conditioned by the sources on with draws, is not necessarily a constant: it may fluctuate according to the credibility of the individual sources." dalam penjelasan di atas Garrachan memaparkan bahwa untuk melakukan kritik sumber haruslah dilakukan secara teliti dan hati-hati agar penulisan sejarah dapat ditulis secara ilmiah. Setelah memahami makna verifikasi di atas, langkah verifikasi yang dilakukan peneliti dalam mengkritik sumber data.

\section{Interprtasi (Teknik Analisis Data)}

Langkah selanjutnya, langkah interpretasi. Interpretasi atau penafsiran sejarah seringkali disebut analisis sejarah. Analisis sendiri berarti menguraikan. Secara terminologis berbeda dengan sintesis yang berarti menyatukan. Mengenai hal tersebut Kuntowijoyo yang dikutip oleh Abdurahman (2012:114) menjelaskan keduanya analisis dan sintesis dipandang sebagai metode utama dalam interpretasi. Analisis itu sendiri bertujuan melakukan sintesis atas sejumlah data yang diperoleh dari berbagai sumber-sumber sejarah dan bersama dengan teori-teori disusunlah fakta itu ke dalam satu interpretasi yang menyeluruh. Dalam proses interpretasi sejarah, peneliti berusaha mencapai pengertian faktor-faktor yang menyebabkan terjadinya peristiwa.

Oleh karena itu, interpretasi dapat dilakukan melalui perbandingan data guna menyikap peristiwa-peristiwa mana yang terjadi dalam waktu yang sama. Jadi jelaslah, untuk mengetahui sebab-sebab dalam peristiwa sejarah itu memerlukan pengetahuan tantang masa lalu sehingga pada saat penelitian, peneliti akan mengetahui situasi pelaku, tindakan, dan tempat peristiwa itu (Abdurahman,2012:115). Hasil dari interpretasi ini, terbentuklah susunan atau karangka yang siap untuk ditulis. 
a. Teknik Deksriptif Analisis

Analsis data adalah proses penghimpunan atau pengumpulan, permodelan dan transformasi data dengan tujuan untuk menyoroti dan memperoleh informasi yang bermanfaat, memberikan saran, kesimpulan dan mendukung pembuatan keputusan.

Analisis data mempunyai banyak variasi pen-dekatan, teknik yang digunakan dan nama atau sebutan bergantung pada tujuan dan bidang ilmu yang terkait (Usman,2004:74). Setelah melalui langkah heuristik dan keritik sumber (verifikasi), selanjutnya yaitu teknik deksriptif analsis. Deskriptif dalam penelitian ini mengambarkan atau memaparkan situs ulak lebar (Maman,2006:29), sedangkan analisa merupakan tahapan yang paling menentukan, karena dalam tahapan ini data dikerjakan sedemikian rupa sehingga dapat menjawab dan menyimpulkan persoalan dalam penelitian ini.

Penggunaan metode deskriptifanalsis terhadap penelitian mengenai rekontruksi sejarah Situs Ulak Lebar merupakan upaya memaparkan dan mendeskripsikan sejarah yang terkandung dalam Situs Ulak Lebar. Kemudian menganalsis dengan interpretasi tentang Situs Ulak Lebar sebagai sejarah lokal.

\section{Historiografi(Teknik Penulisan)}

Langkah akhir penelitian sejarah adalah historiografi. Langkah akhir ini adalah langkah final dari rangkaian penelitian yang dilakukan. Sebagai tahap akhir, penulis menyajikan hasil penelitian dalam bentuk sejarah sebagai sebuah peristiwa yang dituangkan. Dan disusun berdasarkan kronologi atau peristiwa dan sebab akibat.
Historiografi menjadi media mengkomunikasikan hasil-hasil penelitian yang diungkap, diuji (verifikasi) dan diintepretasi. Rekontruksi sejarah akan menjadi baik apabila hasil-hasil pendirian tersebut ditulis (Daliman,2012:99).

\section{C.Pembahasan}

\section{Kondisi Situs Ulak Lebar Saat ini}

Kota Lubuklinggau memiliki peran yang cukup berarti dalam perjalanan sejarah Indonesia khusus-nya di Provinsi Sumatera Selatan. Dari data arkeologi yang ditemukan di wilayah tersebut, telah diketahui bahwa terdapat pemukiman kuno yang diperkirakan telah ada sejak masa prasejarah. Dalam perkem-bangan selanjutnya, meski pengaruh agama Islam telah masuk ke wilayah ini, tetapi tradisi kehidupan masya-rakat prasejarah ternyata masih terus berlanjut seperti yang dapat kita lihat pada Situs Ulak Lebar.

Dari hasil pemetaan wilayah, Situs Ulak Lebar ini terletak di Desa Ulak Lebar, Kelurahan Sidorejo, Kecamatan Lubuklinggau Barat II, yang berjarak kurang lebih sekitar 1,5 km ke arah Barat dari pusat kota. Lokasi situs ini ditandai dengan berdirinya Bukit Sulap, aliran Sungai Kelingi, Sungai Kasie, dan Sungai Ketue.

Sungai Kasie dan Sungai Ketue yang mengalir ke arah selatan agak ke tenggara yang bermuara di Sungai Kelingi. Hal tersebut menunjang sebuah hubungan perekonomian melalui jalur sungai sehingga dikenal dengan istilah Poros Ulu-Ilir, sebab pelayaran dari Sungai Musi yang kemudian memasuki sungai utama yaitu Sungai Kelingi, perahu dagang (Jong-Jong) biasa menepi di sebelah hilir negeri Ulak Lebar. Kemudian para pendatang yang akan mengadakan hubungan dengan elite tradisional di Ulak Lebar dapat 
mengikatkan tali jong-jongnya pada Lubuk Genting Tigas yang berada tepat di pelataran halaman Benteng Kuto Ulak Lebar.

Benteng ini berupa gundukan tanah yang membentang di sisi Barat dan Timur, sedangkan pada sisi Utara dan Selatan berbatasan langsung dengan Sungai Kelingi dan Sungai Ketue yang bertebing curam. Gundukan tanah

yang merupakan dinding benteng mempunyai tinggi $\pm 2 \mathrm{~m}$ dan lebar \pm 4 $\mathrm{m}$. Benteng Ulak Lebar ini berdenah agak membulat dengan pintu masuk terdapat di sisi Timur, sehingga benteng tanah ini disebut juga Benteng Kuto Ulak Lebar, sebab dibuat tinggi dari tiap-tiap sisinya. Benteng Kuto Ulak Lebar ini terbuat dari tanah sebagai dinding benteng yang di bangun dengan membuat pematang lalu ditinggikan, tanahnya diambil dari galian di sekeliling lokasi sehingga dari luar, praktis dinding benteng menjadi tinggi karena bekas tanah menjadi selokan yang dalam. Sehingga benteng dari tanah ini yang tinggi ini disebut Kuto atau Kute. Dalam perkembangannya, sebuah pemu-kiman yang dilengkapi dengan benteng tanah diperkirakan telah ada sejak masa prasejarah, tepatnya pada saat masyarakat telah mengenal kegiatan yaitu bercocok tanam dengan bertani. Pada masa itu pula, pemukimanpemukiman masyarakat sudah mulai menetap sehingga diperlukan

sebuah bangunan yang berfungsi untuk melindungi pemukiman tersebut dari ancaman-ancaman binatang buas maupun serangan dari pengaruh luar di sekitar wilayah pemukiman masyarakat tersebut.

Tradisi megalitik diwujudkan dalam bentuk benda peninggalan antara lain seperti punden berundak-undak, dolmen, sarkofagus, dan menhir.
Bangunan-bangunan dari tradisi megalitik ini umumnya berfungsi sebagai kuburan ataupun tempat pemujaan terhadap roh leluhur. Salah satu tinggalan arkeologi dari tradisi megalitik yang berfungsi sebagai tempat pemujaan tersebut adalah menhir. Menhir ialah batu tegak, yang diletakkan dengan sengaja di suatu tempat untuk memperingati orang yang telah mati. Menhir dianggap sebagai media penghormatan, menampung keda-tangan roh sekaligus menjadi lambang dari orang-orang yang dihormati.

Pemukiman dan benteng tanah di Situs Ulak Lebar, diungkapkan bahwa tradisi bangunan benteng yang terbuat dari tanah termasuk pada tradisi Islam Klasik sekitar abad 14-17 Masehi. Pada masa itu masyarakat Ulak Lebar baru mendapat pengaruh Islam maka tradisi penguburan sudah mulai mengacu pada tradisi Islam, sedangkan batu nisan menggunakan menhir karena pengaruh tradisi lama yang masih di percaya oleh masyarakat. Oleh sebab itu, tradisi megalitik di Situs Ulak Lebar disebut Tradisi Megalitik Berlanjut. Keistimewaan menhir-menhir yang ada di Desa Ulak Lebar, bahwasannya semua menhir berdiri dalam posisi berpasang-pasangan dan masingmasing pasangan berorientasi arah Utara dan Selatan, khas makam Islam dengan menghadap ke Kiblat.

Ukuran pada tiap-tiap menhir berpasangan sangat bervariasi. Menhir yang masih ada saat sekarang berjumlah sekitar 132 buah atau 66 pasang, yang tersebar dari sektor satu sampai sektor tujuh, ada yang berukuran tinggi 0-50 $\mathrm{cm}$, lalu berukuran tinggi $50-100 \mathrm{~cm}$, serta ada pula yang berukuran tinggi diatas $100 \mathrm{~cm}$. Namun jumlah menhir yang berukuran tinggi diatas $100 \mathrm{~cm}$ berjumlah sangat sedikit, jika 
dibandingkan jumlah menhir yang berukuran tinggi $0-50 \mathrm{~cm}$ dan $50-100 \mathrm{~cm}$, dapat dilihat disini bahwa ukuran 0-50 $\mathrm{cm}$ berjumlah 35 buah menhir, ukuran 50-100 berjumlah 80 buah menhir, dan ukuran diatas 100 berjumlah 17 buah menhir. Hal ini menggambarkan bahwa orang-orang atau rakyat biasa jumlahnya lebih besar dibandingkan orang-orang yang status sosialnya tinggi atau menengah. Karena apabila orang yang derajat atau status sosialnya lebih tinggi maka menhir penguburannya lebih besar, sedangkan orang yang statusnya sosialnya lebih rendah bentuk menhir penguburannya kecil dan pendek yang diletakkan di tempat tersendiri dari yang lain. Untuk mempermudah pen-jelasan mengenai persebaran menhir berpasangan tersebut, maka dapat di bagi dalam beberapa sektor, dan setiap sektor di bagi lagi menjadi beberapa grup. Untuk di kawasan Situs Ulak Lebar sendiri terdiri dari 7 buah sektor, yaitu dua sektor berada di Selatan sungai Kelingi (sektor I dan II), satu sektor terletak di sebelah Timur benteng tanah (sektor III), dua sektor dalam kompleks benteng (sektor IV dan V), dan dua sektor terletak di sebelah Barat benteng (sektor VI dan sektor VII), dan ada tambahan dua sektor lagi (sektor VIII dan sektor IX), tetapi letaknya tidak satu komplek dengan Situs Ulak Lebar melainkan di puncak Bukit Sulap.

Untuk menjelaskan secara rinci mengenai sektor-sektor pada menhir berpasangan ialah sebagai berikut:

\section{a. Sektor I}

Sektor I, terdapat 12 pasang menhir yang terbagi atas kelompok A dan B. Kemudian posisi nisan menunjukkan arah Utara dan Selatan. Pada sektor ini juga, tidak ditemukan pecahan gerabah dan keramik yang sudah tidak ada lagi sebab lapisan humus tanah sudah ada tanaman kopi warga di sekitar sektor yang tebal dan lembab.

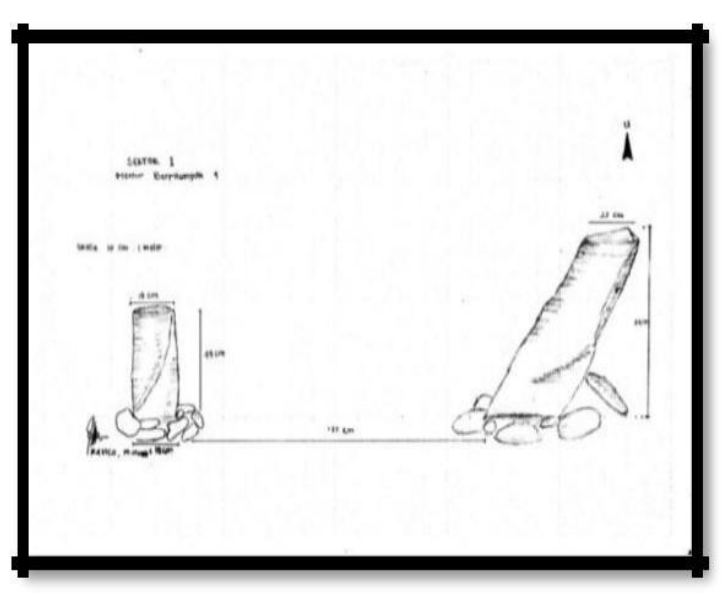

\section{b. Sektor II}

Pada sektor II ini terdapat empat buah grup menhir berpasangan. Luas sektor II sekitar $\pm 36.000 \mathrm{~m}^{2}$. Sektor ini sangat banyak ditemukan pecahan gerabah tanpa ukiran dan pecahan keramik asing. Sejak tahun 1995, sebagian lokasi dari sektor ini dimanfaatkan masyarakat untuk melakukan penambangan pasir dan batu kali sebab letaknya berdekatan dengan bibir sungai utama yaitu Sungai Kelingi. Sehingga berdampak pada kerusakan di sekitaran menhir.

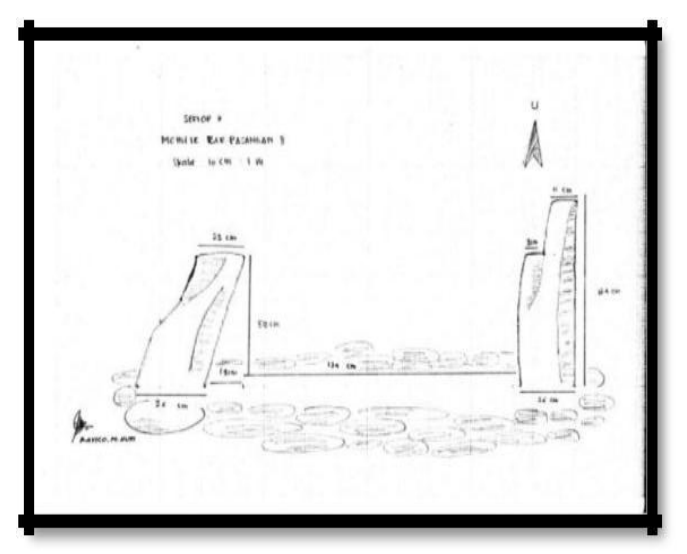

\section{c. Sektor III}

Sektor III terletak di sebelah Timur benteng Kuto yang ke arah Utara Sungai Kelingi dan lebih dekat dengan Sungai Ketue. Jumlah menhir pada sektor III ini sebanyak sekitar 50 pasang dan terbagi menjadi 10 grup. 


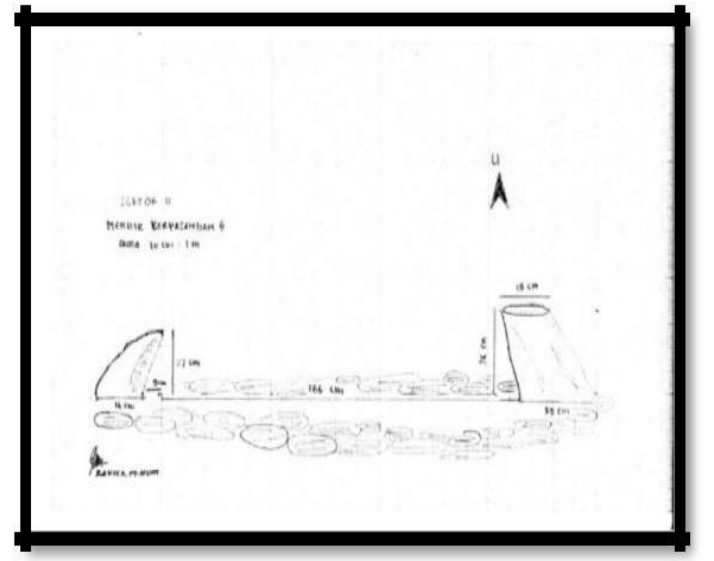

\section{d. Sektor IV dan V}

Sektor IV ini berada di dalam lokasi benteng kuto Ulak Lebar. Dalam hal ini ditemukan berupa sepasang menhir berpasangan berposisi Utara dan Selatan, letaknya hanya 4 meter dari tebing curam tepian sungai Kelingi.

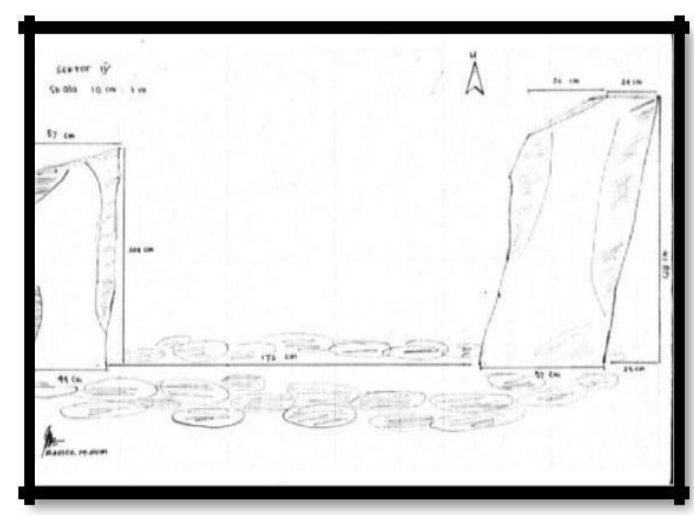

Namun hal yang menarik dari temuan menhir berpasangan di sektor IV ini, diindikasikan merupakan tempat persemayaman terakhir dari sosok Bujang Kurap yang telah menjadi cerita rakyat masyarakat Kota Lubuklinggau.

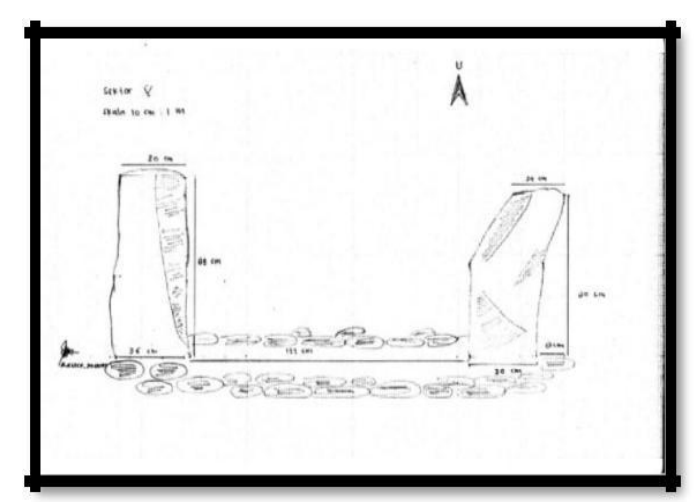

Tak jauh dari menhir berpasangan di sektor IV, yang terpisah oleh jalan proyek irigasi sungai Kasie, terdapat sepasang menhir berpasangan lagi pada sektor $\mathrm{V}$ ini. Namun temuan yang menonjol pada sektor IV dan sektor V ini adalah temuan pecahan keramik asing di sepanjang jalan yang dibuat oleh proyek irigasi sungai Kasie, di hitung dari dalam lokasi benteng ditemukan tidak kurang dari $8 \mathrm{~kg}$ pecahan keramik asing yang bervariasi berasal dari Dinasti Sung, Dinasti Ming, dan Dinasti Ching.

\section{e. Sektor VI dan Sektor VII}

Temuan pada sektor VI dan sektor VII di Ulak Lebar ini mengenai menhir berpasangan tidak ada perubahan. Di sektor VI itu sendiri terdapat satu grup dengan dua pasang menhir berpasangan

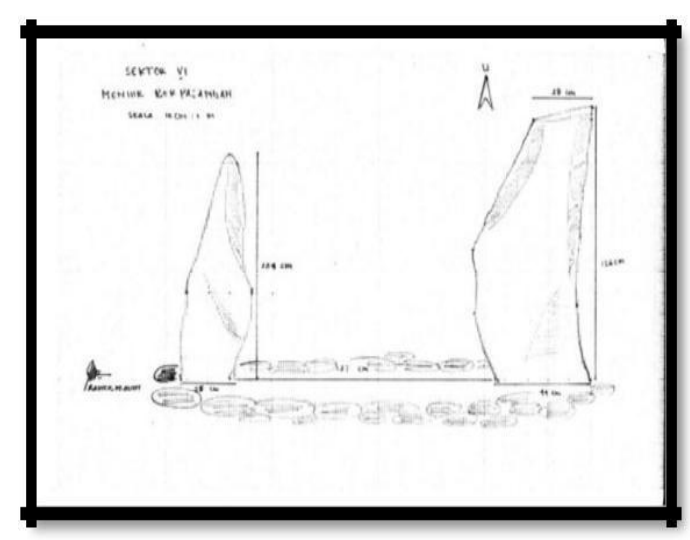

Di sektor VII terdapat dua group dengan tujuh pasang menhir berpasangan.

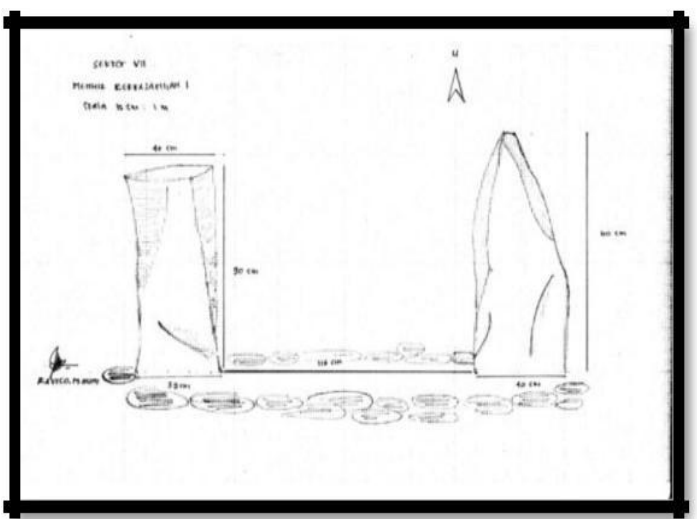




\section{Upaya Pelestarian Situs Ulak Lebar SebagaiDestinasi Wisata Sejarah}

Untuk melestarikan Situs Ulak Lebar ini kami sebagai peneliti ingin mensosialisasikan

atau memperkenalkan kepada teman-teman, masyarakat dan pemerintah, bahwa di Kota Lubuklinggau itu ada peninggalan sejarah pada zaman pra-aksara, seperti, peninggalan batu megalitikum, pecahan keramik cina, dan lain sebagainya. Dimana awal mula peradaban masyarakat Kota Lubuklinggau pertama sekali berada di Ulak Lebar. Oleh karena itu kami sebagai peneliti ingin melestarikan budaya tersebut sebagai destinasi wisata sejarah Kota Lubuklinggau.

\section{Kesimpulan}

Artikel Sejarah yang diberi judul "Pelestarian Situs Ulak Lebar Sebagai Destinasi Wisata Sejarah" dapat ditarik kesimpulan yaitu:

1. Kondisi Situs Ulak Lebar yang terdiri dari tujuh sektor. Dari sektor satu sampai sektor ketujuh perlunya upaya pelestarian baik dari peran pemeritah dan masyarakat. Agar warisan sejarah ini dapat terjaga dengan baik.

2. Dilihat dari peninggalannya dan uapaya pelestariannya Situs Ulak Lebar pantas menjadi destinasi wisata sejarah.

\section{Saran}

Penyusunan artikel ini tidak terlepas dari konstribusi dari Komunitas Pecinta Sejarah Bumi Silampari yang ikut melestarikan dan menjaga peninggalan sejarah. oleh karena itu, masukan dari rekan-rekan maka penyusun banyak mengucapkan rasa terima kasih.

\section{Daftar Referensi}

Abdullah, Taufik.2005. Sejarah Lokal Indonesia. Yogyakarta: Gadjah Mada University Press

2011. Metode Penelitian Sejarah Islam.

Yogyakarta: Ombak

Amir Paialang, Yasraf. 2003. Hipersemiotika Tafsir Cultur Studie Atas Matinya Makna:Yogyakarta: Jalasutra

Daliman, A. 2012. Metode penelitian Sejarah. Yogyakarta: Ombak

Garrachan.1946. A Guide to Hisrorical Method. New York: Fordham University Press.

$\begin{array}{ccc}\text { Gonggong, Anhar. } & \text { 1992. } & \text { Abdul } \\ \text { Qahhar } & \text { Mudzakkar;Dari } & \text { Patriot } \\ \text { Hingga } & \text { Pemberontak. } & \text { Jakarta: } \\ \text { Grasindo } & & \end{array}$

Irwanto, Dedi. 2010. Venesia dari Timur: Memaknai Produksi dan Reproduksi Simbolik Kota Palembang dari Kolonial Sampai Pascakolonial. Yogyakarta : Ombak

Khaldun, Ibnu. $2000 . \quad$ Muqaddimah, diterjemahkan oleh Akhmadi Thoha, Cet II; Jakarta: Pustaka Firdaus

Supriyanto, dkk. 2010.Iliran dan Uluan: Dinamika dan Dikotomi Sejarah Kultur Palembang. Yogyakarta: Eja Publiser

Suryabrata, Sumardi. 1997. Metodelogi Penelitian.Jakarta: Raja Grafindo 